\title{
Xenopus embryos regulate the nuclear localization of XMyoD
}

\author{
Ralph A.W. Rupp, ${ }^{1}$ Lauren Snider, and Harold Weintraub \\ Hutchinson Cancer Research Center, Howard Hughes Medical Institute, Seattle, Washington 98104 USA
}

\begin{abstract}
Injection of Xenopus myoD mRNA into Xenopus embryos leads to only a modest activation of myogenic markers. In contrast, we show that injected mouse myoD mRNA leads to a potent activation. We postulate that XMyoD is under negative control in frog embryos, but because of slight sequence differences, mouse MyoD fails to see the negative signal. Whereas $\mathrm{mMyoD}$ is constitutively nuclear, $\mathrm{XMyoD}$ is largely cytoplasmic except in a region of the embryo that includes the location where mesoderm induction occurs; there, it is nuclear. At MBT, endogenous $X m y o D$ mRNA is expressed ubiquitously in the frog embryo. Our results suggest that this expression would lead to cytoplasmic XMyoD protein. Among other events, muscle induction might remove this negative regulation, allow MyoD to enter the nucleus, and establish an autoregulatory loop that could commit cells to myogenesis.
\end{abstract}

[Key Words: Xenopus; embryos, MyoD; nuclear localization; mRNA expression; myogenesis]

Received February 24, 1994; revised version accepted April 20, 1994.

MyoD (Davis et al. 1987) and the three other members of the myogenic regulatory gene family (MRF)-myogenin (Wright et al. 1989), Myf-5 (Braun et al. 1989), and MRF4/ herculin/Myf-6 (Rhodes and Konieczny 1989; Braun et al. 1990; Miner and Wold 1990)-are structurally related, muscle-specific DNA-binding proteins of the basic helix-loop-helix (bHLH) class (Murre et al. 1989; Benezra et al. 1990). Upon forced expression in vitro, each member of the MyoD family is capable of initiating the myogenic differentiation program in cultured fibroblasts by binding directly to controlling sequences of muscle-specific regulatory and structural genes. Whereas the other MRFs have not been tested extensively, MyoD is also capable of initiating myogenesis in a large number of other differentiated cell types (Weintraub et al. 1989; Choi et al. 1990; Miner et al. 1992). Once expressed, the various members of the MyoD family can, depending on the specific conditions, autoactivate themselves and cross-activate each other. This may help to integrate complex requirements for muscle differentiation as well as to stabilize the muscle phenotype. Genetic knockout experiments in mice suggest that $\mathrm{MyoD}$ and Myf-5, while having unique functions (Braun et al. 1992; Rudnicki et al. 1992), also share a redundant function (Rudnicki et al. 1993) in committing cells to muscle and determining the myoblast state; myogenin seems to be primarily responsible for converting committed myoblasts to overtly differentiated muscle (Hasty et al. 1993; Nabeshima et al. 1993; for recent reviews, see Weintraub

${ }^{1}$ Present address: Friedrich Miescher Laboratorium, Max-Planck Gesellschaft, D-72076, Tübingen, Germany. et al. 1991a; Buckingham 1992; Olson 1992; Emerson 1993; Weintraub 1993).

In Xenopus laevis there are two XmyoD genes termed $X m y o D a$ and $X m y o D b$ (Hopwood et al. 1989; Harvey 1990; Scales et al. 1990), which are derived from two nonallelic loci of the pseudotetraploid Xenopus genome (Kobel and DuPasquier 1986). Muscle cells originate from the deep layers of the equatorial region or marginal zone of frog embryos during mesoderm induction (Nieuwkoop 1969; Keller 1975; for recent reviews, see Kimmelman et al. 1992; Slack 1993), a process thought to occur from as early as the 36-cell stage and proceeding on into gastrulation (Jones and Woodland 1987). However, the commitment to muscle cell identity may not occur until late gastrula stages, when cells first become capable of differentiating cell-autonomously irrespective of the embryonic environment (Kato and Gurdon 1993). Highlevel expression of $X m y o D$ and $X m y f-5$ genes has been localized to the presumptive mesoderm from early gastrula stages on (Hopwood et al. 1989; Harvey 1990; Scales et al. 1990; Hopwood et al. 1991). In addition, it has been shown that the myoD genes can be activated in tissue explants from the animal hemisphere ("animal caps") by agents that induce mesoderm in vitro (Hopwood et al. 1989; Harvey 1990; Rupp and Weintraub 1991).

Whereas the results above suggest a direct link between the transcriptional activation of the myogenic genes and the determination of myoblasts, several other observations complicate this hypothesis: First, frog eggs contain a maternal XmyoDa RNA pool, which is not localized to prospective muscle-forming regions (Hopwood et al. 1989; Harvey 1990; Rupp and Weintraub 
1991). Second, at the midblastula transition (MBT), which marks the onset of zygotic gene expression (Newport and Kirschner 1982), both myoD genes are transiently transcribed at low levels everywhere in the embryo in a process that is not dependent on mesoderm induction (Rupp and Weintraub 1991). Finally, overexpression of XMyoD and XMyf-5 proteins by RNA injection into embryos leads to rather poor induction of marker muscle structural genes and does not induce ectopic myogenesis (Hopwood and Gurdon 1990; Hopwood et al. 1991). All three of these observations suggest that in the frog embryo, mere expression of XMyoD is not sufficient for myogenesis and that either additional positive factors are needed or the embryo actively represses XMyoD activity, or both.

In the present study we address this issue directly. We show that while microinjected $X m y o D$ mRNA is a poor activator of genomic XMyoD and myogenesis (e.g., see Hopwood and Gurdon 1990), mouse MyoD is a potent activator. This suggests that in the early frog embryo $\mathrm{XMyoD}$ protein is under negative control, but because of amino acid sequence differences, the $\mathrm{mMyoD}$ protein fails to see these negative signals. Overexpressed $\mathrm{mMyoD}$ is located in the nucleus in all regions of the embryo; in contrast, overexpressed XMyoD is largely cytoplasmic, except in a localized region that includes the presumptive mesoderm. There, it is nuclear. The cytoplasmic retention of XMyoD protein is saturable at high levels of XMyoD expression and fails to be bypassed by inclusion of an SV40 nuclear localization signal (NLS). The inhibitory domain for cytoplasmic retention of frog MyoD maps largely to the carboxy-terminal third of frog MyoD. When present in nuclei, MyoD protein-either frog or mouse-is sufficient to stably activate myogenesis ectopically in the embryo. Our results lead to the suggestion that frog embryos regulate the intracellular localization of XMyoD protein as a consequence of muscle induction. We hypothesize that once nuclear, MyoD can activate its own transcription and commit a cell to the myogenic lineage (Thayer et al. 1989; Rupp and Weintraub 1991). The use of related proteins from different species may prove to be a general approach to uncover subtle forms of species specific regulation.

\section{Results}

Microinjected mmyoD RNA results in a much better activation of muscle-specific gene expression in frog embryos than microinjection of frog myoD RNA

In Xenopus, zygotic transcription of myoD first occurs transiently and throughout the embryo at the MBT. This result is somewhat paradoxical, because it is known that MyoD can autoactivate its own transcription and, at least in tissue culture cells, can convert many cell types to muscle. This clearly does not happen at the MBT. To understand why MBT-myoD mRNA does not apparently activate MyoD expression and myogenesis throughout the embryo, we have overexpressed MyoD by injection of synthetic RNAs into embryos (Fig. 1).
After MBT, we isolated blastocoel roof explants /animal caps), which normally do not form muscle on their own (Gurdon et al. 1985). They were cultivated until sibling embryos had reached neural tube stages, well beyond the time at which somite-specific expression of MyoD is established (Frank and Harland 1991; Hopwood et al. 1992). We then prepared RNA from these explants and analyzed it by reverse transcription-polymerase chain reaction (RT/PCR) (Rupp and Weintraub 1991).

As we reported previously, MBT-myoD mRNA has decayed by this time and animal caps from uninjected control embryos contain no detectable $X m y o D$ and very little cardiac $\alpha$-actin RNA (Fig. la, lane 2; see Rupp and Weintraub 1991). Injection of even high doses of $X m y o D b$ RNA (up to 3 ng; see Fig. 1 legend) causes only very little activation of endogenous $X m y o D$ and cardiac actin genes, although the animal caps still contain large amounts of the injected RNA [lanes 5,8 (see also Hopwood and Gurdon 1990)|]. The same result was observed with injection of both wild-type $X m y o D a$ and $X m y o D b$ RNAs (data not shown). In transient transfection assays, however, all of our $X m y o D$ cDNAs were as myogenic as mouse MyoD. Each activated a cotransfected muscle creatine kinase-chloramphenicol acetyltransferase (MCKCAT) reporter construct 200 - to 1000 -fold over background in $3 \mathrm{~T} 3$ cells, and each converted $3 \mathrm{~T} 3$ fibroblasts into muscle (5-20\% of cells) (data not shown).

These discrepancies can be explained by the hypothesis that XMyoD is inhibited by the embryonic environment. If so, then it is likely that a specific site(s) on $\mathrm{XMyoD}$ might be responsive to this inhibition and mutation of such a site(s) could lead to a molecule that was resistant to inhibition. A convenient way to generate mutations is to take advantage of the natural sequence divergence between mouse and frog myoD. Because the early developmental strategies of frogs and mice can be rather different in detail, and because these different strategies might be reflected in differences in the primary structure of the mouse versus the frog MyoD, the effect of $\mathrm{mMyoD}$ overexpression was assayed in animal caps. Injection of even $<1 \mathrm{ng}$ of mmyoD RNA causes a dramatic trans-activation of both endogenous $X m y o D$ and cardiac actin genes (lane 7). On the basis of molar amounts of the various injected mRNAs [which are translated with similar efficiencies in vitro (data not shown) and in vivo (Fig. 1b)], we estimate that $\mathrm{mMyoD}$ trans-activates $>100$-fold better than $\mathrm{XMyoD}$ in this assay. Fusion proteins of $\mathrm{mMyoD}$ with the acidic transactivation domain of the herpes simplex virus VP16 protein are even more potent trans-activators than wildtype $\mathrm{mMyoD}$. Thus, a potent activation of musclespecific genes can be achieved with injection of physiological RNA amounts [Fig. la, lane 3; see also Fig. 3, below; Xenopus gastrulae contain $\sim 20 \mathrm{pg}$ of XmyoD RNA (see Hopwood et al. 1989)]. A similar XMyoDbVP16 fusion protein was again $>100$-fold less active than mMyoD-VP16, although it was highly myogenic in transient transfection assays with $3 \mathrm{~T} 3$ cells (data not shown).

Expression of nonmuscle genes such as EF-1a and GS17 is unaffected by mMyoD (e.g., Fig. 2), and the ac- 
Animal Caps NF19

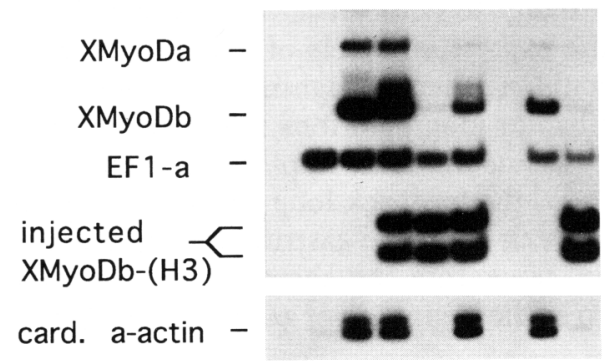

$\begin{array}{llllllll}1 & 2 & 3 & 4 & 5 & 6 & 7 & 8\end{array}$

b

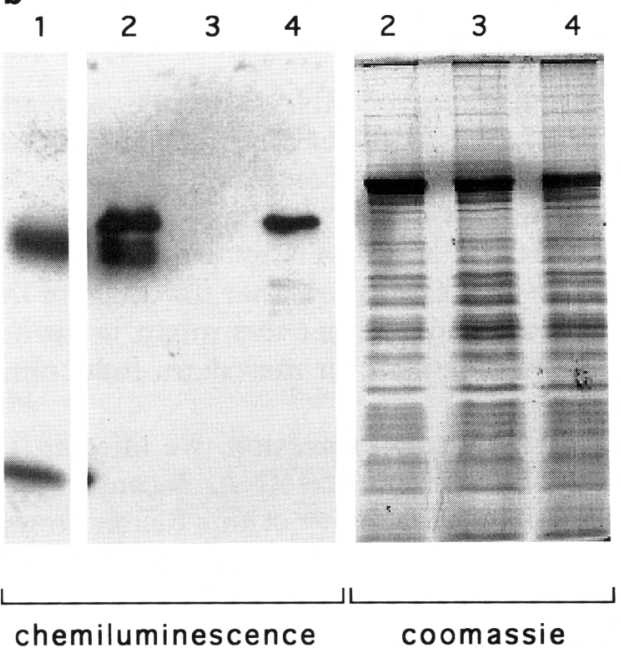

Figure 1. (a) Trans-activation of muscle-specific genes by frog and mouse MyoD proteins in animal cap explants. Both cells of two-cell embryos were injected near the animal pole with various amounts of capped, nonpolyadenylated synthetic RNAs encoding MyoD proteins. Animal cap explants were dissected from control and injected embryos after MBT and cultured in neutral saline until sibling embryos reached late neurula stages. Total cellular RNA was then prepared, reverse-transcribed, and analyzed by multiplex PCR for the presence of EF1 $a$ and XmyoD RNAs, and by single-primer pair PCR for cardiac actin RNA. After amplification, all multiplex PCR samples were subjected to a HindIII digest, which results exclusively in cleavage of the PCR product derived from the injected $X m y o D(H 3)$ RNA. This engineered variant behaves identically to wild-type XMyoD, but its levels of expression can be distinguished from endogenous MyoD because of the presence of the HindIII site (see Materials and methods|. PCR fragments generated from EF-1a (EF1-a) or endogenous XmyoD RNAs contain no HindIII restriction site. Injected myoD RNAs are not detected by primers specific for $X$ myoD-coding regions. (Lane 1) Mock RT/PCR, no template; (lane 2) uninjected control embryos. Embryos were injected with the given amount of RNAs encoding the following proteins: (lane 3) mMyoD-VP16 (0.03 ng); (lane 4) coinjection of mMyoD-VP16 (0.03 ng) and XMyoDb(H3) (1.5 ng); (lane 5) $\mathrm{XMyoDb}(\mathrm{H} 3)$ (1.5 $\mathrm{ng}$ ); (lane 6) coinjection of mMyoD (0.75 ng) and $\mathrm{XMyoDb}(\mathrm{H} 3)$ (1.5 ng); (lane 7) $\mathrm{mMyoD}$ (0.75 ng); (lane 8) $\mathrm{XMyoDb}(\mathrm{H} 3)$ (3 ng). (b) Injected embryos contain similar levels of overexpressed frog and mouse MyoD proteins. Embryos were injected with $2 \mathrm{ng}$ of synthetic RNAs lacking the SV40 poly(A) signal, which encode $M T X m y o D b$ and $M T m m y o D$, respectively. At late gastrula, whole cell protein extracts were prepared from animal halves of embryos and analyzed for exogenous protein in Western blots with the Myc tag-specific $\mathrm{mAB}$ 9E10. (Lane 1) In vitro-translated MTXMyoDb protein (10-sec exposure); protein extracts in the following lanes $(90-\mathrm{sec}$ exposure) represent $M T X m y o D b$ RNA-injected embryos (lane 2) uninjected embryos (lane 3), and MTmmyoD RNA-injected embryos (lane 4). Protein from one embryo half was loaded per lane (vegetal halves contained minor amounts of overexpressed proteins at equal abundance; data not shown). Coomassie staining of these extracts on a second gel run in parallel reveals equal total protein contents of the different extracts.

tivation of muscle-specific genes requires both the MyoD basic region, as well as a trans-activation domain (not shown). Neither the bHLH region alone nor a mMyoD-VP16 mutant, in which the MyoD basic region has been replaced with the basic region of the nonmyogenic $\mathrm{HLH}$ protein E12, was sufficient to activate $X m y o D$ or cardiac actin genes (data not shown). Thus, these mutant and variant MyoD molecules behave identically in Xenopus embryos as in mouse tissue culture cells (note that the $\mathrm{mMyoD}$ bHLH region alone can activate myogenesis in stable, but not transient transfection, assays (Davis et al. 1987). Surprisingly, the coinjection of Xenopus and mouse myoD RNAs at various molar ratios did not affect the trans-activation of endogenous muscle genes by $\mathrm{mMyoD}$ protein (Fig. 1a, cf. lanes 4 and 6 with lanes 3 and 7). This indicates that at these concentrations, the frog and mouse $\mathrm{MyoD}$ proteins do not compete for limiting factors involved in the transactivation of these genes, or that the two MyoD proteins are in different cellular compartments.

We conclude that $\mathrm{mMyoD}$ is a much better activator of muscle-specific genes in frog embryos than XMyoD.
One explanation for these results is that normally frog embryos negatively regulate the activity of XMyoD, but $\mathrm{mMyoD}$ is missing the domain that responds to this negative regulation.

\section{The endogenous XmyoD genes do not become competent for autoactivation until gastrula stages}

The existence of maternal myoD RNA, which is derived from the XmyoDa gene (Hopwood et al. 1989; Harvey 1990; Rupp and Weintraub 1991), raises the possibility that the ubiquitous expression of MyoD at MBT or the induced expression at gastrula might result from autoactivation. To address this, we first injected embryos with RNA encoding a fusion protein consisting only of the mMyoD bHLH region with the VP16 trans-activation domain [mMyoD(bHLH)-VP16]. RNAs encoding this MyoD derivative have turned out to be the most potent transcriptional activators of muscle genes in frog embryos (data not shown). Cellular RNA from animal cap explants harvested shortly after MBT (Fig. 2B, lane 2) showed no increase in the steady-state levels of the en- 


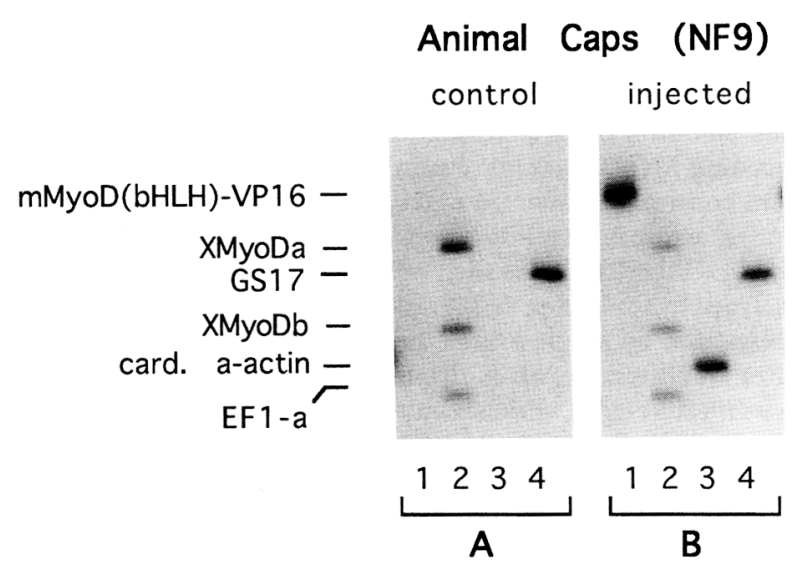

Figure 2. The MyoD-positive feedback loop does not operate at MBT. At the late blastula stage (NF9), animal caps were dissected from control embryos $(A)$ or embryos that were injected at the two-cell stage with $0.01 \mathrm{ng}$ of RNA encoding mMyoD(bHLH)-VP16 protein and lysed immediately for RNA purification $(B) . \mathrm{RT} / \mathrm{PCR}$ analysis was performed in parallel with the primer pairs detecting either the injected mmyoD $(b H L H)-V P 16$ RNA (lanes 1) or endogenous mRNAs (lanes 2-4). (Lanes 2) Multiplex PCR for $E F-1 a$ and $X m y o D a$ and $X m y o D b$ RNAs; (lanes 3) cardiac $\alpha$-actin RNA; (lanes 4) GS17 RNA. The signals for $\mathrm{XMyoDa}$ and XMyoDb represent general MBT-specific transcription of these genes.

dogenous $X m y o D$ RNAs compared with animal caps from uninjected control embryos (Fig. 2A, lane 2). Expression of the unrelated EF-1 $a$ and GS17 genes, which are also transcribed at MBT (Krieg and Melton 1985; Krieg et al. 1989), was also not affected (cf. lanes 2 and 4 of $A$ and $B$, respectively|. However, the cardiac actin gene was prematurely activated (Fig. $2 \mathrm{~B}$, lane 3 ), indicating that the injected RNA had been translated and that this protein is capable of trans-activating muscle genes at this particular time in development. The same result has been obtained with injection of wild-type mmyoD RNA (data not shown). We conclude that at MBT and in contrast to the cardiac actin gene, which can be activated by $\mathrm{mMyoD}$, the endogenous $X m y o D$ genes are not competent for autoactivation and that additional factors are required for activating transcription of the endogenous myoD genes at MBT. Interestingly, these genes are competent in templating the low level ubiquitous transcription observed at MBT.

To investigate whether maternal myoD mRNA is required for subsequent myogenic activation, either at MBT or at gastrula, we have used antisense oligonucleotides to specifically degrade over $95 \%$ of the maternal $X m y o D a$ mRNA. This had no effect on the MBT activation of XMyoDb (data not shown; see Materials and methods). Interpretation of these results is complicated because we cannot rule out the possibility that a small amount of undetectable maternal MyoD protein contributes to subsequent activation at MBT or gastrula. It is also important to point out that these experiments do not address the function of MBT-expressed XMyoD in later muscle induction because the injected oligonucleotide is likely to be degraded by the time of MBT. Because the expression levels of the $X m y o D$ genes at the MBT could neither be significantly increased nor decreased by our manipulations, the MyoD autoactivation circuitry seems not to be in place during blastula stages. Apparently, the feedback loop becomes established only later (between MBT and gastrulation), where it may play a role in generating the sharp increase of myoD transcription at the beginning of gastrulation (Hopwood et al. 1989).

The high-level expression of muscle-specific genes by $m M y o D$ cannot be maintained in animal caps by autoactivation of the endogenous $\mathrm{XmyoD}$ genes

The injection of mmyoD RNA into embryos represents a transient assay, as both the RNA and the encoded protein are degraded because of normal turnover. We have exploited this fact to ask whether endogenous XMyoD, once activated to high levels by exogenous $\mathrm{MyoD}$, can maintain its own expression after the decay of the exogenous message and whether this might be sufficient to bypass the requirement for mesoderm induction to initiate myogenesis.

To initiate $\mathrm{XMyoD}$ expression, we injected embryos with mmyoD(bHLH)-VP16 RNA. Because of the very high transcriptional activity of this fusion protein, very little synthetic RNA is needed. This RNA only persists until neural tube stages, after which it is no longer detectable in animal cap explants because of normal turnover processes (Fig. 3, C-E, lanes 1). Up to this time, the $\mathrm{mMyoD}(\mathrm{bHLH})-\mathrm{VP} 16$ protein maintains expression of

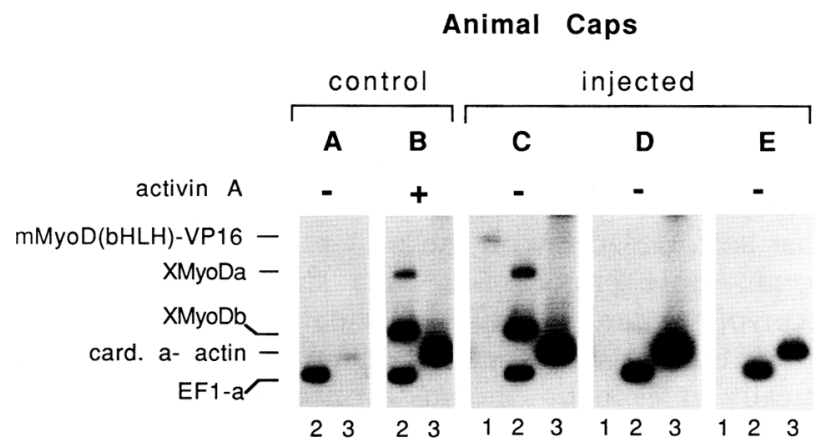

Figure 3. High levels of endogenous $X m y o D$ mRNAs are not sufficient to maintain expression of $X m y o D$ genes through autoactivation in uninduced animal cap explants. At the late blastula stage, animal caps were dissected from control embryos $(A, B)$ or embryos injected with $(0.01 \mathrm{ng})$ RNA encoding $\mathrm{mMyoD}(\mathrm{bHLH})-\mathrm{VP} 16$ protein $(C-E)$, cultured in neutral saline $(A, C-E)$ or in the presence of activin $\mathrm{A}(0.5 \mathrm{ng} / \mathrm{ml} ; B)$ until siblings had reached neural fold (NF17; $A-C$ ), tailbud (NF30; $D$ ), or hatching stages $(\mathrm{NF} 36 ; E)$. RNA was prepared from each stage and analyzed by RT/PCR with primers specific for the injected mmyoD(bHLH)-VP16 RNA (lanes 1) endogenous EF-1 $a$ and $X m y o D a$ and XmyoDb RNAs (lanes 2; multiplex PCR), and cardiac $\alpha$-actin RNA (lanes 3) (see Materials and methods). 
the endogenous $X m y o D$ and cardiac actin genes (Fig. $3 \mathrm{C}$ ). Most importantly, the steady-state levels of the endogenous RNAs were similar to those found in animal cap explants of the same age, which had been incubated with activin A (Fig. 3B). This potent mesoderm-inducing factor is known to induce expression of $\mathrm{XMyoD}$ as well as myogenesis under these conditions (Asashima et al. 1990; Thomsen et al. 1990; Rupp and Weintraub 1991). As soon as the injected RNA disappeared, however, transcription of the $X m y o D$ genes was greatly diminished (Fig. 3D) and finally stopped (Fig. 3E). The steady-state level of cardiac actin RNA was clearly reduced as well, although it did not disappear completely, possibly reflecting differences in RNA stability between $X m y o D$ and cardiac actin mRNAs.

This result clearly establishes that the ectopic activation of muscle-specific genes in animal caps depends entirely on the presence of the mMyoD-VP16 fusion protein, and that XMyoD protein, translated from the endogenous mRNA and induced to high levels by $\mathrm{mMyoD}-$ VP16, is no better a trans-activator than the ectopic XMyoD protein, translated from synthetic RNA. It seems very unlikely that this difference between mouse and Xenopus MyoD is attributable to a translational control of the endogenous $X m y o D$ mRNA, as the microinjected $X m y o D$ RNAs are translated very efficiently (see below). Thus, the combined results described in Figures 1-3 suggest two types of negative control over XMyoD autoactivation. First, at MBT, the genes are resistant to autoactivation and there is only a low level of transcription. Second, at later stages, the endogenous gene in animal caps is capable of high-level expression when activated by $\mathrm{mMyoD}$, but the endogenous XMyoD protein is incapable of sustaining the positive feedback loop needed for high-level expression.

\section{Frog embryos regulate the subcellular localization of ectopically expressed XMYoD protein}

These experiments demonstrate a striking difference in trans-activation activity between mouse and Xenopus MyoD proteins in the frog embryo. This raises the question whether their relative protein concentrations are the same in vivo. To address this question we monitored the various MyoD proteins by fusing them to an epitope tag (Myc tag; Evan et al. 1985; Roth et al. 1991; see Materials and methods). Expression of the resulting fusion proteins from microinjected RNA was then analyzed by whole-mount immunocytochemistry (Hemmati-Brivanlou and Harland 1989), using the Myc tagspecific monoclonal antibody 9E10 (mAb 9E10)(Evan et al. 1985). In the absence of injected RNA, this antibody recognizes no endogenous protein (Fig. 4j). Embryos were assayed at late gastrula stages, after completion of mesoderm induction (Jones and Woodland 1987), and at about the time when the specific expression pattern of $\mathrm{XMyoD}$ in the presomitic mesoderm becomes fixed (Frank and Harland 1991; Hopwood et al. 1992).

Endogenous XMyoD protein levels are detectable from about the midgastrula stage onward, and the proteins are found exclusively in nuclei of those mesodermal cells that are committed to form muscle (Hopwood et al. 1992). Unexpectedly, lateral views of whole mounts from injected embryos expressing Myc-tagged XMyoDa and XMyoDb proteins (Fig. 4a,d) show staining of two different kinds: patchy staining over the animal hemisphere of the embryos, but punctate staining in the region directly above the yolk plug (i.e., the induced marginal zone; for overview, see Fig. $4 \mathrm{~m}$ ). At higher magnification, explants taken from the blastocoel roof region of these embryos (Fig. 4b,e) reveal that the patchy staining represents $\mathrm{XMyoD}$ protein that is predominantly localized in the cytoplasm of these cells. Very rarely do we find cells in this region that show both cytoplasmic and nuclear staining. In contrast, the punctate staining in the marginal zone represents predominantly nuclear XMyoD protein (Fig. 4c,f). The differential localization of exogenous XMyoD between animal hemisphere and marginal zone is seen in both superficial and deep cells (see Fig. 4c,f,n). This is particularly important in the involuting marginal zone, as these epithelial cell layers should become endoderm and eventually form the archenteron roof but apparently do not contribute to muscle (Suldarwati and Nieuwkoop 1971; Keller 1975). Thus, there is a suggestion that at this time in development the region in which exogenous XMyoD can enter the cell nucleus includes, but does not exactly match, the muscle fate map region. We also note that the transition from cytoplasmic to nuclear XMyoD protein localization occurs gradually in a zone in which cells with predominantly cytoplasmic, both cytoplasmic and nuclear, and predominantly nuclear XMyoD protein are mixed (Fig. 5).

In contrast to the localization of XMyoD, embryos expressing Myc-tagged $\mathrm{mMyoD}$ show punctate staining everywhere (Fig. 4g), and explants from animal pole and marginal zone identify it clearly as predominantly nuclear staining in both regions (Fig. 4h,i). The epitope tag itself does not influence the subcellular localization of either Xenopus or mouse MyoD proteins. When expressed alone the epitope tag is always found in the cytoplasm (Fig. 4k,l), even in regions where frog and mouse MyoD proteins are nuclear. We have also confirmed the differential localization of frog and mouse MyoD by using RNAs encoding wild-type proteins/without an epitope tag) and corresponding antibodies to mouse and Xenopus MyoD proteins. For example, untagged XMyoD protein is localized cytoplasmically in deep-layer cells of

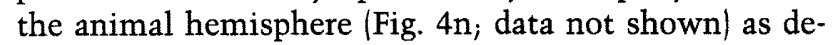
tected with the XMyoD-specific mAb D7F2 (Hopwood et al. 1992) after mRNA injection. These results also indicate that the exogenous $\mathrm{XMyoD}$ protein is present at much higher concentration than the endogenous $\mathrm{XMyoD}$ protein, which is present in nuclei of muscle precursor cells (Hopwood et al. 1992) but is not detected under these staining conditions in the cells at this time in development. In separate experiments /data not shown), injection of Myc-tagged frog myf-5 RNA (Hopwood et al. 1991) gave a predominant cytoplasmic distribution similar to XMyoD in the animal hemisphere, 
Figure 4. Intracellular localization of overexpressed MyoD proteins. Capped, nonpolyadenylated synthetic RNAs (2 ng) were injected into the animal pole region of two-cell embryos. At late gastrula stages (NF11 $1 / 2-12$ ), embryos were fixed and subjected to whole-mount immunocytochemistry using either the Myc tag-specific mAb 9E10 (all pictures except $n$ ) or the XMyoD-specific mAb D7F2 (n only; Hopwood et al. 1992). Bound primary antibodies were detected with alkaline phosphatase-conjugated goat anti-mouse $\mathrm{mAb}$ and NBT/BCIP staining. RNAs encoded the following proteins: $(a-c)$ Myc-tagged $\mathrm{XMyoDa}$; $(d-f)$ Myc-tagged XMyoDb; $(g-i)$ Myc-tagged mMyoD; (j) uninjected control embryos; $(k, l)$ Myc epitope tag only. (n) Animal pole region from an embryo injected with non-Myc-tagged $X m y o D b$ RNA and stained with XMyoD-specific $\mathrm{mAb} .(a, d, g)$ Lateral view of injected embryos with animal pole at top and yolk plug at the bottom. High magnification view of blastocoel roof explants: $(b, e, h, k)$ epithelial cell layer; $(n)$ sensorial cell layers. $\{c, f, i, l\}$ High magnification view of marginal zone explants. Note the staining of nuclei in deep layer cells of embryos injected with RNAs encoding Myc-tagged $\mathrm{XMyoD}$ proteins $(c, f$, arrows). $(m)$ Schematic overview of gastrula regions displaying differential intracellular localization of XMyoD. Horizontal lines above the yolk plug indicate the approximate positions of involuting marginal zone (IMZ) and noninvoluting marginal zone (NIMZ). The shading represents presumptive mesoderm in the deep layers of the IMZ (redrawn after Keller 1991). w m
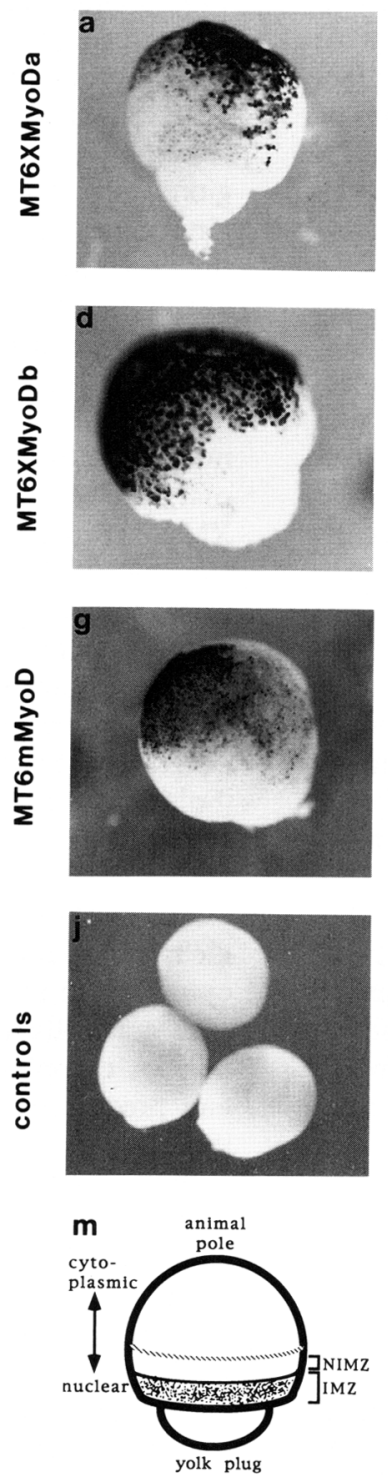

ap
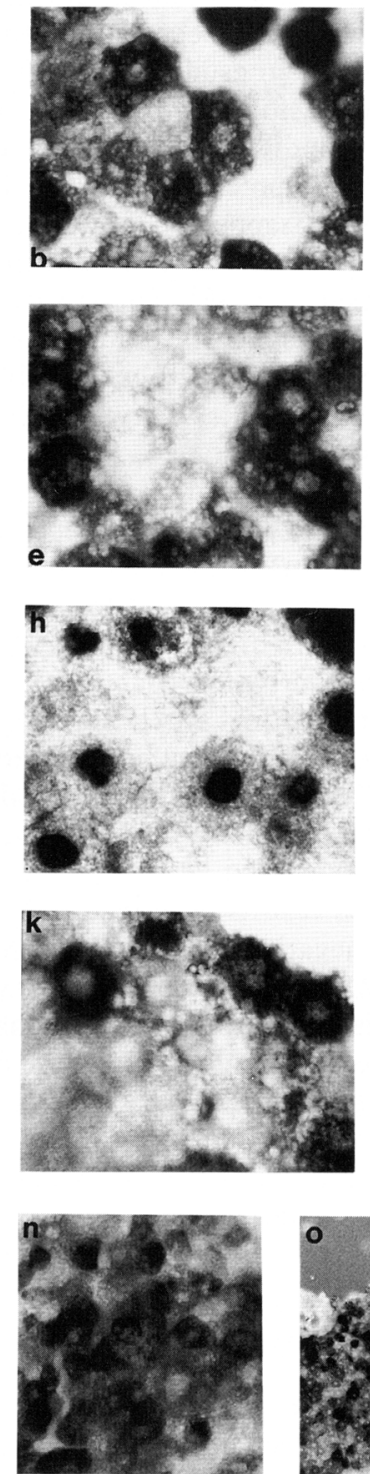

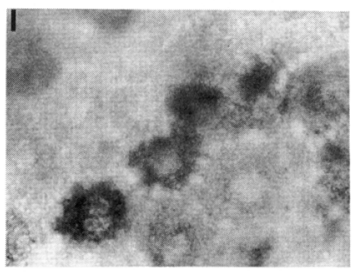

mz
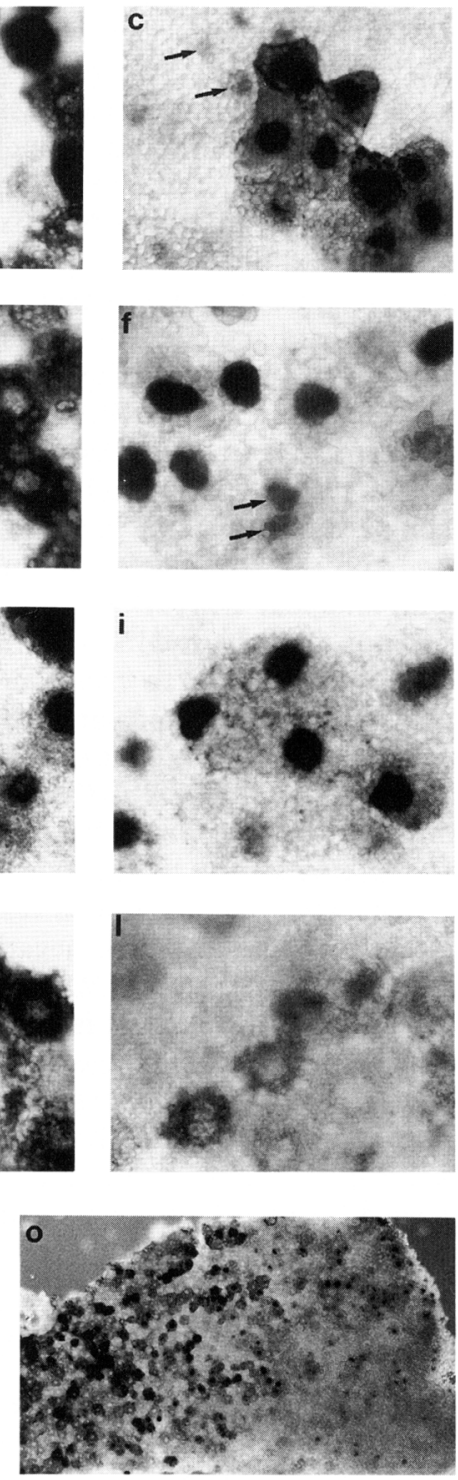

whereas injection of a different Myc-tagged bHLH RNA, for Xenopus twist (Hopwood et al. 1989), gave a nuclear localization throughout the embryo. Injected XMyoD seems to be modified after injection when compared with mMyoD (Fig. 1b lane 2). The nature of this modification and whether it is related to the mechanism of retention is currently being studied.

To try to localize the putative domain in XMyoD that causes cytoplasmic localization, variants were generated that lack either the carboxyl terminus $(\Delta C)$, the amino terminus $(\Delta N)$ or both $(\Delta N, \Delta C)$ (Table 1). Removal of the carboxy-terminal third greatly enhances nuclear localization, whereas removal of the amino-terminal third of $X M y o D$ has no effect on its own, yet it potentiates the effect of the carboxy-terminal truncation. The bHLH $(\Delta N, \Delta C$ MyoD), which contains the NLS (e.g., see Tap- scott et al. 1988; Vandromme et al. 1994), can enter the nucleus (Table 1) on its own. These results suggest that the target for cytoplasmic retention lies largely in the carboxy-terminal third of MyoD, but there is some contribution by the amino-terminal third as well. Finally, addition of the SV40 NLS fails to provide XMyoD access to the nucleus (Table 1), again suggesting that there is a specific mechanism for retention.

Differential subcellular localization offers a simple explanation for the qualitative difference in trans-activation activities of mouse and Xenopus MyoD proteins described earlier. XMyoD protein apparently fails to transactivate muscle-specific genes ectopically because it cannot enter the nuclei of animal cap cells. mMyoD, on the other hand, is much more active because its nuclear access is apparently not restricted. Although nuclear lo- 


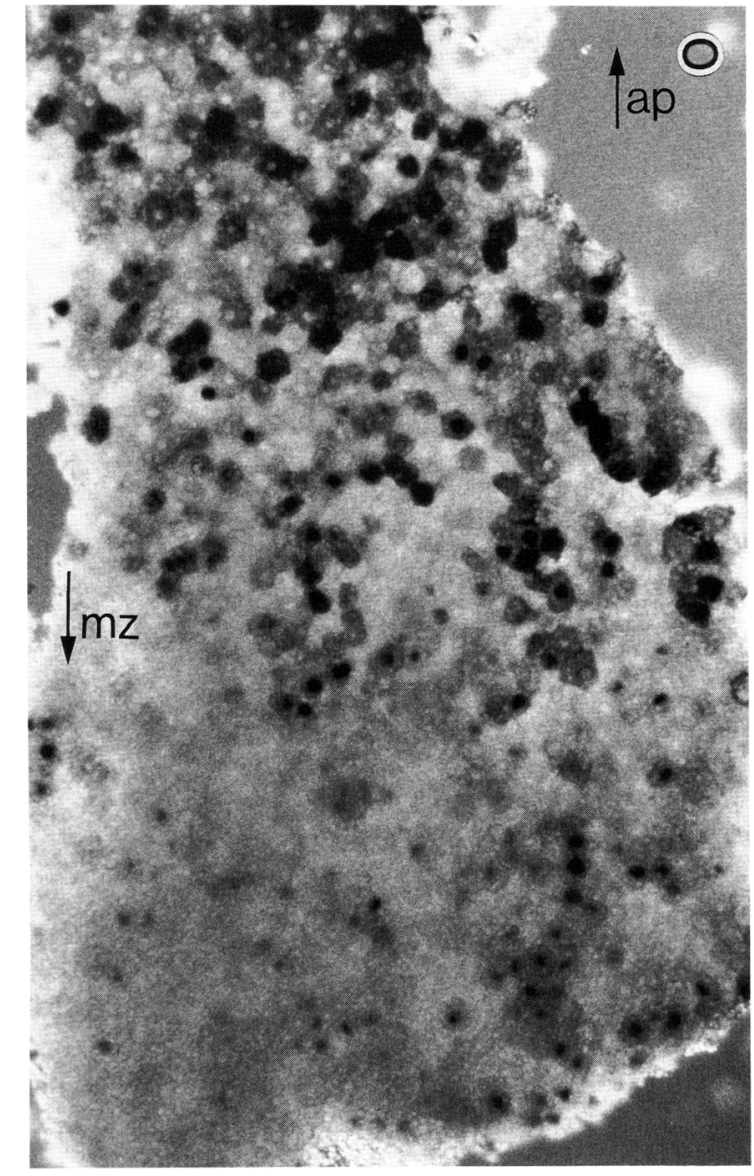

Figure 5. Transition zone between nuclear and cytoplasmic MyoD. Myc-tagged XmyoD RNA was injected and assayed as in Fig. 4. The photo shows an area extending from the animal pole (ap) to the marginal zone $(\mathrm{mz})$ of a stained, dissected gastrula stage whole mount (enlargement of Fig. 4o).

calization can contribute to inactivation of XMyoD, additional mechanisms cannot be excluded. Most importantly, the observation that XMyoD protein is found in different cellular compartments in distinct regions of the embryo strongly suggests that embryos regulate the nuclear transport of MyoD as a function of induction (see also Dreyer 1987).

\section{Nuclear MyoD protein can ectopically activate late markers of myogenic differentiation and myogenesis}

The weak effects observed with injection of high amounts of XmyoD RNA (Fig. 1, lanes 5,8) and the rare existence of strongly stained cells with both cytoplasmic and nuclear XMyoD protein (see above) suggested the existence of a threshold concentration, above which $\mathrm{XMyoD}$ protein might be able to accumulate in nuclei of cells from the animal hemisphere. It is difficult to further increase $\mathrm{XMyoD}$ protein levels by injecting more synthetic RNA without disrupting gastrulation and decreasing survival (data not shown). However, the trans- lational efficiency of our synthetic RNAs, which ends shortly after the stop codon, could be increased dramatically in vivo by including the SV40 poly(A) signal from the $\mathrm{pCS}^{+}$vector (Fig. 6).

Poly(A) tails have been found to increase RNA stability and translational efficiency in many different systems, including Xenopus embryos (Harland and Misher 1988; Munroe and Jacobson 1990; Gallie 1991). The relative increase in translational efficiency of these injected RNAs might be attributable to processing and polyadenylation in vivo. On Northern gels, injected $X m y o D$ RNA containing the SV40 poly(A) signal is more stable than the corresponding $X m y o D$ mRNA without the poly(A) signal; it also migrates more slowly after injection, suggesting that poly $(\mathrm{A})$ is being added (data not shown).

Inspection of animal hemispheres from embryos that were injected with $X m y o D b$ RNA containing the SV40 poly(A) signal revealed expression of much more protein from the poly(A)-containing RNA (Fig. 6). Under these conditions, the exogenous XMyoD protein was localized largely, but not entirely, in the nucleus (Fig. 6, inset). Although we cannot rule out additional factors [e.g., timing or duration of translation of the injected RNA or some "targeting" activity of the poly(A) signal], the simplest explanation for this shift in intracellular localization of overexpressed $\mathrm{XMyoD}$ protein is that cytoplasmic retention of XMyoD in animal cap cells can be saturated.

At protein levels that are high enough to allow for nuclear access, $\mathrm{XMyoDb}$ protein is capable of activating both endogenous $X m y o D$ and cardiac actin genes in the animal cap assay (data not shown), similar to its murine homolog at much lower protein concentrations (Figs. 1 and 3). We also asked whether frog and mouse MyoD proteins could cause ectopic expression of myosin heavy chain $(\mathrm{MyHC})$ (Bader et al. 1982) and the epitope recognized by mAb 12/101 ("12/101 antigen"; Kintner and Brockes 1984) as representatives of late myogenic markers. Most commonly, overexpression of either frog or mouse $M y o D$ resulted in a bent and shortened body axis with deficiencies of various degrees in head and tail structures (Fig. 7), a phenotype we regard as "nonspecific" because other injected bHLH proteins give similar changes (data not shown). Both muscle markers were expressed up to at least tailbud stages in many tissues outside of the somitic mesoderm, including epidermis, central nervous system, cranial neural crest, and lateral plate mesoderm. Many of the ectopically stained cells are of roundish shape, and the markers are apparently expressed at somewhat lower levels than in myotomal cells (see Fig. 7 legend). Under these conditions, mMyoD overexpression still resulted in a phenotype slightly more pronounced than XMyoD. This not only is evident in the absolute number of cells that express muscle markers ectopically (Fig. 7, cf. b-d with e-f; data not shown) but also in the fact that a higher percentage of these cells show the spindle-shaped morphology of differentiated myocytes (Fig. 7, cf. g and $h$; data not shown). Although this may simply reflect differences in RNA 
Table 1. Deletion analysis of Xenopus MyoDb

\begin{tabular}{llccc}
\hline Injected RNA & $\begin{array}{l}\text { Nuclear } \\
(\%)\end{array}$ & $\begin{array}{l}\text { Nuclear/ } \\
\text { cytoplasmic } \\
(\%)\end{array}$ & $\begin{array}{l}\text { Cytoplasmic } \\
(\%)\end{array}$ & Total no. \\
\hline MTXMyoDb & 0 & $2(4)$ & $49(96)$ & 51 \\
MTXMyoD $\Delta \mathrm{N}$ & 0 & 0 & $32(100)$ & 32 \\
MTXMyoDb $\Delta \mathrm{C}$ & 0 & $45(51)$ & $42(49)$ & 87 \\
MTXMyoDb $\Delta \mathrm{N}, \Delta \mathrm{C}$ & $27(100)$ & 0 & 0 & 27 \\
NLSMTXMyoDb & 0 & 0 & $16(100)$ & 16 \\
\hline
\end{tabular}

The amino and carboxyl terminus of frog MyoD contribute to cytoplasmic localization; the bHLH region does not. mRNAs encoding frog MyoD (Myc tagged) missing either the amino terminus $(\Delta N)$ or the carboxyl terminus $(\Delta C)$, or both $(\Delta N, \Delta C)$ were injected into frog embryos and assayed for nuclear localization as described in Fig. 3. Entries represent percentage of embryos showing predominantly nuclear, cytoplasmic, or both nuclear and cytoplasmic staining. Addition of the SV40 NLS (NLS MTXMyoDb) did not overcome the cytoplasmic localization.

and/or protein stability, it could also indicate that mMyoD escapes additional negative controls imposed on XMyoD besides the regulation of its intracellular localization. These results show that cells outside somitic mesoderm are responsive to $\mathrm{MyoD}$, and these nonmyogenic cells can be stably diverted to the myogenic lineage in intact frog embryos. The patchy distribution of these converted cells may only reflect a mosaic distribution of injected RNA or protein, or possibly, a more profound phenomenon. This is currently being tested.

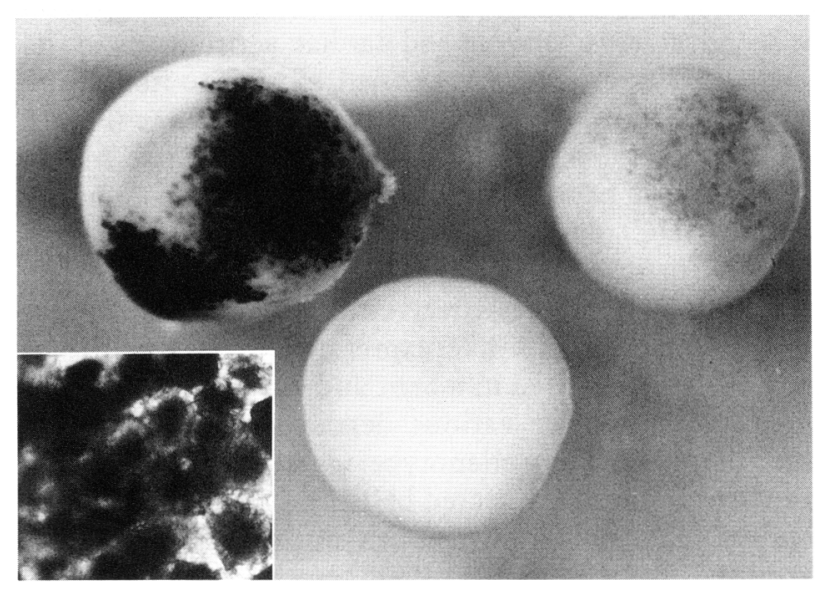

Figure 6. A threshold for cytoplasmic retention of XMyoD protein. Capped RNAs, which either contain or lack the SV40 polyadenylation signal, were transcribed from the vector pCS2 ${ }^{+}$ MTXMyoDb in vitro and injected into the animal hemisphere of two-cell embryos. At gastrula stages, embryos were fixed and subjected to immunocytochemistry with mAb $9 \mathrm{E} 10$ for detection of the overexpressed Myc-tagged XMyoDb protein. The right embryo was injected with 2 ng of RNA lacking the SV40 polyadenylation signal; the embryo in the middle represents and uninjected control; the left embryo was injected with $0.5 \mathrm{ng}$ of RNA containing the SV40 polyadenylation signal. Embryos were stained in parallel for $30 \mathrm{~min}$. (Inset) High magnification view of the animal pole region of the embryo that was injected with RNA containing the SV40 polyadenylation signal. Exogenous protein is present in both cytoplasm and $\mathrm{r}$ iclei.

\section{Discussion}

Although certain defining activities of a given protein can be conserved during evolution, imposed on these defining activities may be less conserved, potential regulatory functions encoded elsewhere in the protein. For example, the bHLH region of myogenic proteins, but little else of the protein, is highly conserved from organisms as unrelated as sea urchins, flies, worms, and man. The putative regulatory functions defined by the less conserved regions may be specific to the unique requirements of the individual organism. Hence, when challenged, a homologous protein from a different organism may exhibit the conserved "basic" function of that protein (e.g., the capacity to induce myogenesis), but nevertheless, behave rather differently in detail from its endogenous counterpart because it fails to be recognized by regulatory factors. In the particular case of myogenesis, we have taken advantage of this possibility to uncover an unexpected type of regulation imposed by the frog embryo upon XMyoD. Thus, the early frog embryo negatively regulates $\mathrm{XMyoD}$ but fails to regulate $\mathrm{mMyoD}$. This seems to be reflected, at least in part, in differences in subcellular localization. A related approach has independently been put forth by Whiteway et al (1992). These examples show that the use of heterologous proteins can be a potent method for unmasking potential regulatory mechanisms in a wild-type background.

We have presented evidence that ectopically overexpressed XMyoD protein is under negative control in the animal hemisphere of frog embryos. The molecular basis of this repression is apparently a block to nuclear transport causing exogenous XMyoD to accumulate in the cytoplasm. At present, we cannot rule out the possibility that additional negative controls also contribute to the repression of frog versus mouse MyoD. We believe that cytoplasmic localization of $\mathrm{XMyOD}$ is attributable to specific retention for the following reasons: (1) At very high protein concentrations XMyoD can enter nuclei in the animal hemisphere. Under these conditions, it transactivates muscle-specific genes ectopically, and a percentage of these cells adopts the elongated morphology of differentiated myocytes (Fig. 7). (2) Removal of the 
a

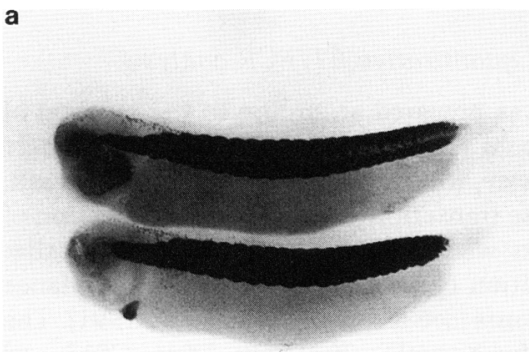

c

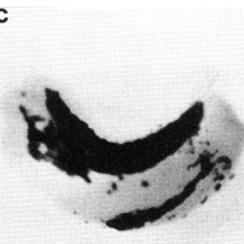

d

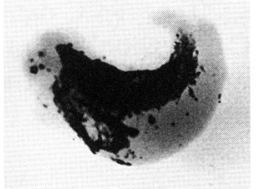

g

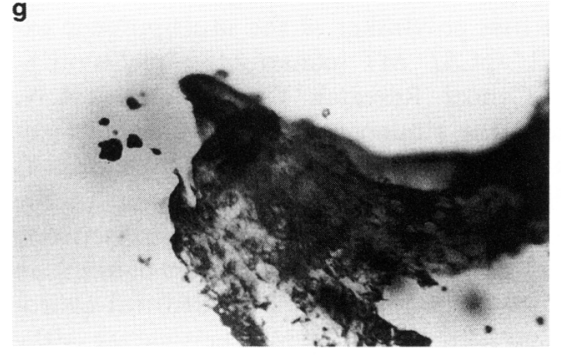

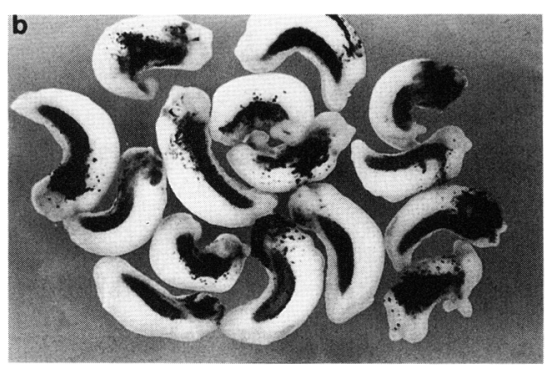

e

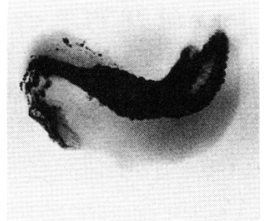

n

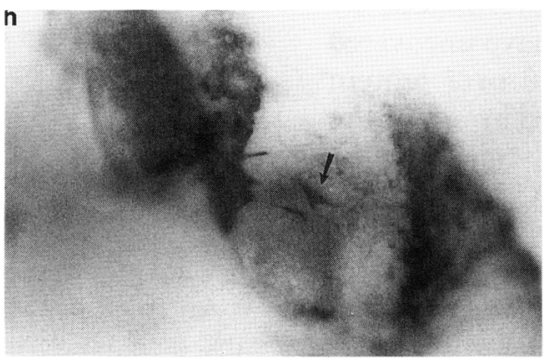

Figure 7. Ectopic activation of myogenic marker genes by overexpression of $\mathrm{MyoD}$ proteins. Embryos were injected with 0.25 ng of RNAs that contain the SV40 polyadenylation signal and encode either $\mathrm{mMyoD}(b-\mathrm{d}, g)$ or XMyoDb $(e-f, h)$ protein. Expression of muscle-specific proteins was analyzed at stage NF34 (heartbeat; Nieuwkoop and Faber 1967) by immunocytochemistry. All embryos, except those shown in $b$, were cleared in 1:2 BABB. (a) Uninjected sibling embryos, which were stained for MyHC (bottom) or 12/101 epitope (top). Staining is restricted to the somitic mesoderm and, in the case of MyHC, also to the heart. (b) Injected with mmyoD; stained with anti-myosin heavy chain (MyHC). (c) Injected with mmyoD; stained with anti-MyHC. $(d)$ Injected with mmyoD; stained with mAb $12 / 101$. (e) Injected with $X m y o D$; stained with antiMyHC. $(f)$ Injected with $X m y o D$; stained with $\mathrm{mAb} 12 / 101$. Every embryo shows at least some, and in many cases, extensive, expression of $\mathrm{MyHC}$ or $12 / 101$ outside the somitic mesoderm. $g$ and $h$ are blow-ups of injected embryos shown in $d$ and $f$. Both show 12/101 epitope-positive cells in ectopic positions, whose elongated morphology resembles that of differentiated myocytes in the somitic mesoderm. In general, myotomal staining became visible at least twice as fast as staining in ectopic places. carboxyl terminus of XMyoD [the least conserved domain between Xenopus and mouse MyoD (Scales et al. 1990|] allows nuclear entry, and the additional removal of the amino terminus gives almost complete nuclear localization (Table 1). (3) Addition of the SV40 NLS to $\mathrm{XMyoD}$ fails to provide nuclear localization.

In the presumptive mesoderm, exogenous XMyoD is localized in the nucleus, as is the endogenous protein (Hopwood et al. 1992). We conclude that cytoplasmic retention can be a major determinant of the activity of ectopically expressed XMyoD. At a mechanistic level, we favor the idea that XMYD is being anchored in the cytoplasm and some consequence of the induction process releases $\mathrm{XMyoD}$ from the anchor. It is also possible that XMyoD might be preferentially degraded in nuclei, and induction might prevent this and stimulate cytoplasmic degradation. A variety of known inhibitors of MyoD (e.g., Id, Jun, Fos, protein kinase C) could be involved in the inhibition process in frog embryos; however, because many of these inhibitors are known to be directed at the MyoD bHLH domain and because this domain in isolation can enter the nucleus, we think that most of these known inhibitors are unlikely participants in the inactivation of $\mathrm{MyoD}$ in frog embryos.

The differences in localization of $\mathrm{mMyoD}$ and XMyoD can be attributed to sequence divergence between the two proteins (XMyoDa and XMyoDb proteins share $83 \%$ overall sequence identity with each other, but only $\sim 70 \%$ with mMyoD; see Scales et al. 1990) such that $\mathrm{mMyoD}$ can bypass the negative control that retains $\mathrm{XMyoD}$ protein in the cytoplasm. So far, the intracellular localization of myogenic proteins has not been known to be subject to regulation. In transfection experiments both $\mathrm{mMyoD}$ and XMyoD protein are nuclear in mouse cells in all conditions tested to date (data not shown, although see Vandromme et al. 1994). Finally, our experiments have also uncovered a second type of control on endogenous MyoD transcription. Although exogenous $\mathrm{mMyoD}$ or large amounts of XMyoD can activate the cardiac actin gene at MBT, the endogenous $X m y o D$ genes are resistant to autoactivation until early to mid-gastrula. The basis for this and particularly whether it is a cis-acting (e.g., chromatin) or trans-acting effect (e.g., coactivator) is not known.

A number of transcription factors seem to be regulated by translocation from the cytoplasm to the nucleus in response to an appropriate signal (for review, see Whiteside and Goodbourn 1993). One of the best studied cases is the dorsal protein, whose graded nuclear uptake along the dorsal-ventral axis of the Drosophila embryo is a function of the signal transduction cascade encoded by the dorsal group genes (Roth et al. 1989; Rushlow et al. 1989; Govind and Stewart 1991). Similarly, we have observed a gradual transition from cytoplasmic to nuclear 
localization for exogenous XMyoD protein along the animal-vegetal axis of the Xenopus embryo (Fig. 5). Whether the two phenomena are mechanistically related remains to be seen. It is also intriguing to consider the possibility that nuclear access of XMyoD in the marginal zone might be the result of an induction signal. Primary mesoderm induction is thought to occur as early as blastoderm stages (Jones and Woodland 1987); however, exogenous $\mathrm{XMyoD}$ is both nuclear and cytoplasmic in the marginal zone at that time (data not shown). Therefore, it is possible that the putative signals occur later, perhaps involving the Noggin or Wnt pathways as well (Christian et al. 1991; Sokol et al. 1991; Smith and Harland 1992; for review, see Sive 1993; Woodland 1993).

Finally, it is important to emphasize that our MyoD localization experiments relate only to protein translated from exogenously introduced mRNA. We presume that endogenous protein, particularly from MBT-MyoD, would behave similarly; however, the level of MBT RNA is too low to expect a corresponding amount of protein to be detectable by the usual methods. Nevertheless, by probing with injected RNAs, our results have uncovered an unexpected type of embryonic control over protein localization, one that seems to be regulated by one of the inducing systems present in the intact frog embryo. Once present in the nucleus, $\mathrm{MyoD}$ can, in principle, activate its own transcription and commit a cell to the myogenic lineage (Thayer et al. 1989; Rupp and Weintraub 1991).

\section{Materials and methods \\ Embryo handling}

In vitro fertilization of eggs, culture of embryos, dissections, and activin induction of animal cap explants were performed as described (Rupp and Weintraub 1991). For overexpression of MyoD proteins, embryos were dejellied in $2 \%$ cysteine $1 \mathrm{hr}$ after fertilization and placed at $15^{\circ} \mathrm{C}$ in $0.1 \times$ modified Barth's saline (MBS) until injection. At the two-cell stage they were injected with $\sim 5 \mathrm{nl}$ of synthetic RNA into each cell near the animal pole and cultivated either at room temperature or at $15^{\circ} \mathrm{C}$ until the desired stage. Embryos were staged according to Nieuwkoop and Faber (1967).

\section{Antisense knockout of maternal XmyoDa RNA}

Embryos were injected at the two-cell stage with $5 \mathrm{ng}$ of partially modified antisense oligodeoxynucleotides, containing phosphoamidate phosphodiester linkages at both termini to increase stability (indicated by asterisks below; see Dagle et al. 1991). Two of these oligodeoxynucleotides were specific for $X m y o D a$ RNA, that is, antiXMD- $1\left[5^{\prime}-\mathrm{C}^{*} \mathrm{~T}^{*} \mathrm{C}^{\star} \mathrm{C}^{\star} \mathrm{TCCT}-\right.$ CCTCG ${ }^{\star} T^{\star} G^{\star} C^{\star} \mathrm{C}-3$ ', position 284-268; (Scales et al. 1990)] and anti-XMD-2 $\left[5^{\prime}-G^{\star} T^{\star} C^{\star} G^{\star} T C A T A G A A G^{\star} T^{\star} \underline{G}^{\star} G^{\star} T-3^{\prime}\right.$, position 182-166 (Scales et al. 1990); mismatches to corresponding $X m y o D b$ regions are underlined]. Control injections included $\mathrm{H}_{2} \mathrm{O}$ and an unrelated $\beta$-globin control oligonucleotide $\left(5^{\prime}-C^{\star} A^{\star} T^{\star} G^{\star} G T G C A C C T G{ }^{\star} A^{\star} C^{\star} T^{\star} G-3\right\rangle$. Total cellular RNA was prepared at various time points from whole embryos or animal caps and subjected to RT/PCR analysis to measure specificity and completeness of XmyoDa RNA degradation be- fore $\mathrm{MBT}$ and the activation of $X m y o D b$ gene transcription shortly after MBT.

\section{RNA purification and quantitative RT/PCR analysis}

Total cellular RNA was prepared according to the method of Chomczynski and Sacchi (1987), but employing only a single ethanol precipitation step, followed by one $70 \%$ ethanol wash. Random primed reverse transcription and PCR amplification of gene-specific fragments were performed under conditions that ensure a direct correlation between RNA template abundance and PCR product amounts (see Rupp and Weintraub 1991). The gene-specific primers for XmyoDa, XmyoDb, EF-Ia, GS17, and cardiac $\alpha$-actin have been described (Rupp and Weintraub 1991). To detect the injected mmyoD(bHLH)-VP16 RNA we performed $28 \mathrm{PCR}$ cycles $\left(30 \mathrm{sec}, 94^{\circ} \mathrm{C}\right.$ denaturation, $30 \mathrm{sec}, 56^{\circ} \mathrm{C}$ annealing, $60 \mathrm{sec}, 72^{\circ} \mathrm{C}$ extension) with the primer pair used for cloning this mutant (see below). RNA sets shown are derived from single experiments and represent typical results.

\section{Vector construction}

All coding regions were subcloned into either $\mathrm{pSP} 64 / 65$ vectors (Promega) or into the first polylinker of the multipurpose expression vectors $\mathrm{pCS} 2^{+} / \mathrm{pCS} 2^{+} \mathrm{MT}$ /constructed by David L. Turner, Hutchinson Cancer Research Center, and R.A.W. Rupp). pCS2 + contains the simian cytomegalovirus IE94 enhancer/promoter that functions in most tissue culture cells as well as frog and zebrafish embryos, an SP6 promoter in the $5^{\prime}$-untranslated region of the IE94 driven transcript to facilitate in vitro RNA synthesis, followed by two polylinkers flanking an SV40 late polyadenylation site. pCS2 ${ }^{+} \mathrm{MT}$ is identical except that it contains a hexameric repeat of the Myc epitope tag at the 5 '-end of the first polylinker. A detailed description of the $\mathrm{pCS} 2{ }^{+}$vectors is available upon request.

The full-length coding regions only of $X m y o D a / b$ were cloned into $\mathrm{pCS} 2^{+} / \mathrm{pCS} 2^{+} \mathrm{MT}$ by PCR with a common forward primer 5'-CTGAATTCTGCCATGGACCTCTTGCCCCCA-3', and two gene-specific reverse primers, 5'-GATCTAGACTATAAGATCTGGTAGATGGT-3' (XMyoDa)/5' -GATCTAGACTATAAGACGTGATAGATGGT-3' (XMyoDb), respectively (initiator and stop codons are indicated by bold letters, and $E c o R I-X b a I$ sites are underlined. The forward primer includes a single, silent mismatch to the $X m y o D b$ template).

The amino-terminal deletion $(\Delta \mathrm{N})$ of $\mathrm{XMyoDb}$ was generated with the forward primer 5'-CTGAATCCAATGCCGACAGGAGGAAGGCC-3' [position 411-433, deletion of amino acids 1-92 (Hopwood et al. 1989)] in combination with the XMyoDbspecific reverse primer. The carboxy-terminal deletion $(\Delta C)$ of $\mathrm{XMyoDb}$ was generated using the common forward primer (see above) in combination with the reverse primer $5^{\prime}$-CTGAATTCAAGGCGCCCTGGTCGTGGAGCAGAGC-3' [position 578-589; deletion of amino acids 154-289 (Hopwood et al. 1989); this primer also introduces a NarI site, encoding a GA dipeptide, immediately upstream of the stop codon]. PCR amplification with the forward primer used for the amino-terminal deletion, in conjunction with the reverse primer used for the carboxy-terminal deletion, produced the XMyoD $\Delta \mathrm{N} \Delta \mathrm{C}$ mutant, which encodes the bHLH region only. All of these mutants were caroboxy-terminally fused to the Myc tag repeats of $\mathrm{pCS} 2{ }^{+} \mathrm{MT}$. pCS2 $2^{+}$NLSMTXMyoDb was cloned by introducing the NLS of the SV40 large $\mathrm{T}$ protein as a BamHI-Clal fragment $15^{\prime}$ GGATCCGCCGCCATGGCTCCAAAGAAGAAGCGTAAGGTAAATCGAT-3') into PCS2 + MTXMyoDb.

For the XMyoDb $(\mathrm{H} 3)$ variant a HindIII restriction site was engineered at nucleotide position 791 of $X m y o D b$ (Hopwood et 
al. 1989) by PCR mutagenesis (Higuchi 1990) with the overlapping primer pair 5'-TCAGTGATCTCCAAGCTTGACTGCCTCTCC-3' (forward)/5'-GGAGAGGCAGTCAAGCTTGGAGATCACTGA-3' (reverse; HindIII site underlined, mutated nucleotides in boldface type), in combination with the above-mentioned primers located at the ends of the coding region. This mutation, which changes $S_{219}$ to $N$, does not interfere with the ability of XMyoD to induce myogenesis in tissue culture cells (data not shown). As templates we used a conventionally isolated $X m y o D b$ cDNA or a PCR-cloned XmyoDa cDNA (Rupp and Weintraub 1991). Full-length mmyoD was transferred as an EcoRI fragment from the original pEMSVscribeMyoD1 expression vector (Davis et al. 1987). This included the untranslated regions. Fragments containing only the coding region were obtained by PCR with the primer pair 5'-CTGAATTCCAGGAACTGGGATATG-3' (forward)/ $5^{\prime}$-GTTGGATCCTCAAAGCACCTGATAAATCG-3' ${ }^{\prime}$ (reverse; EcoRI-BamHI sites underlined, initiator and stop codons in boldface type). The mMyoD-VP16 cDNA has been described (Weintraub et al. 1991b) and was subcloned as an EcoRI fragment. mmyoD(bHLH)-VP16 was generated by PCR from the template $\triangle \mathrm{N} \triangle \mathrm{CMyoD}-\mathrm{VP16}$ (Weintraub et al. 1991b) with the primers 5'-GTAGATCTGGATATGGAGCTCAAGCGCAAGACCAC-3' (forward) / 5'-GATCTAGACTACCCACCGTACTCGTCAA-3' (reverse; initiator and stop codons in boldface type, BglII-XbaI sites underlined). The TC dinucleotide marked in bold in the forward primer frames a gap from nucleotide position 168 to 462 , which deletes amino acids 4-101 of mMyoD (Tapscott et al. 1988). The reverse primers hybridize to the $3^{\prime}$ end of the VP16 trans-activation domain (see Weintraub et al. 1991b).

\section{In vitro $R N A$ synthesis}

Plasmids were linearized with $\mathrm{XbaI}$ [pSP65XMyoDb-(H3), $\mathrm{pCS}^{+}$ MT-XMyoDa, pCS2 $\left.{ }^{+} \mathrm{XMyoDb}, \mathrm{pCS} 2{ }^{+} \mathrm{mMyoD}\right]$ and HindIII [pSP65mMyoD, pSP65mMyoD-VP16, pSP64mMyoD(bHLH)VP16] to generate RNAs without a SV40 polyadenylation signal), or Asp 718 (pCS2 ${ }^{+} \mathrm{XMyoDb}, \mathrm{pCS} 2^{+} \mathrm{MTXMyoDb}, \mathrm{pCS} 2{ }^{+}$ $\mathrm{mMyoD}$ ) to generate RNAs containing the poly $(\mathrm{A})$ signal. Capped SP6 transcripts were synthesized from $2.5 \mu \mathrm{g}$ of template in a $50-\mu l$ reaction mix [ $1 \times$ transcription buffer (Promega), $1 \mathrm{~mm}$ DTT, 40 units of RNAsin (Promega), $0.5 \mathrm{~mm}$ each of ATP, CTP, GTP, and UTP, $2.5 \mathrm{~mm}$ of $\mathrm{G}\left(5^{\prime}\right) \mathrm{ppp}\left(5^{\prime}\right) \mathrm{G}$ cap analog (New England Biolabs)]. Fifty units of SP6 polymerase was added at the beginning, with another 25 units after $2.5 \mathrm{hr}$. Total incubation time at $37^{\circ} \mathrm{C}$ was $4-5 \mathrm{hr}$, followed by a $30-\mathrm{min}$ DNase digest 10-20 units of RNase-free DNase I (Stratagene), and purification of the RNA by phenol extraction, passage over G50 spin columns, and EtOH precipitation. RNAs were redissolved in DEP-treated $\mathrm{H}_{2} \mathrm{O}$ and stored at $-70^{\circ} \mathrm{C}$.

\section{Immunocytochemistry}

Embryos were derived from fertilization of albino eggs with wild-type sperm. Immunocytochemistry was performed essentially as described by Hemmati-Brivanlou and Harland (1989), with the exception that embryos were placed in sieves and transferred through standard solutions in 24-well tissue culture dishes (see Turner and Weintraub 1994). Tissue culture supernatants of 9E10 (Evan et al. 1985), MF20 (Bader et al. 1982), and D7F2 (Hopwood et al. 1992) hybridomas were diluted 1:5; the $12 / 101$ (Kintner and Brockes 1984) supernatant was used undiluted. Bound primary antibodies were detected with goat antimouse alkaline phosphatase secondary antibody /diluted 1:4000, Boehringer). After fixing the stain, some embryos were cleared in 1:2 benzyl alcohol/benzyl benzoate (BABB; Dent et al. 1989).

\section{Embryo extracts}

Whole-cell protein extracts were generated and subjected to Western blot analysis as described (Hopwood et al. 1992). Overexpressed proteins were detected by chemiluminescence (ECL substrate, Amersham) after incubating the blots with Myc tagspecific mAb 9E10 (1:5 diluted tissue culture supernatant) and horseradish peroxidase-conjugated goat anti-mouse secondary antibody (1:5000 diluted, Dianova).

\section{Acknowledgments}

We thank all members of our laboratory for helpful comments and criticism, especially Dave Turner and Stan Hollenberg. We thank Allan Zahler, Mark Roth, Stan Hollenberg, Amy Cheng, and John Gurdon for providing plasmids, oligonucleotides, and antibodies. The technical assistance of Ute Ehringer and Stephanie Dawson is also acknowledged. Activin A was a gift from Genentech. This work was supported by the Howard Hughes Medical Institute and the National Institutes of Health. R.A.W.R. was supported by a postdoctoral fellowship of the Muscular Dystrophy Association (MDA).

The publication costs of this article were defrayed in part by payment of page charges. This article must therefore be hereby marked "advertisement" in accordance with 18 USC section 1734 solely to indicate this fact.

\section{References}

Asashima, M., H. Nakano, K. Shimada, K. Kinoshita, K. Ishii, H. Shibai, and N. Ueno. 1990. Mesodermal induction in early amphibian embryos by activin A (erythroid differentiation factor). Wilhelm Roux's Arch. Dev. Biol. 198: 330-335.

Bader, D., T. Masaki, and D.A. Fischman. 1982. Immunochemical analysis of myosin heavy chain during avian myogenesis in vivo and in vitro. J. Cell Biol. 95: 763-770.

Benezra, R., R.L. Davis, D. Lockshon, D.L. Turner, and H. Weintraub. 1990. The protein Id: A negative regulator of helixloop-helix DNA binding proteins. Cell 61: 49-59.

Braun, T., G. Buschhausen-Denker, E. Bober, E. Tannich, and H.H. Arnold. 1989. A novel human muscle factor related to but distinct from MyoD1 induces myogenic conversion in 10T1/2 fibroblasts. EMBO J. 8: 701-709.

Braun, T., E. Bober, B. Winter, N. Rosenthal, and H.H. Arnold. 1990. Myf-6, a new member of the human gene family of myogenic determination factors: Evidence for a gene cluster on chromosome 12. EMBO I. 9: 821-831.

Braun, T., M.A. Rudnicki, H.H. Arnold, and R. Jaenisch. 1992. Targeted inactivation of the muscle regulatory gene Myf-5 results in abnormal rib development and perinatal death. Cell 71: 369-382.

Buckingham, M. 1992. Making muscle in mammals. Trends Genet. 8: 144-149.

Choi, J., M.L. Costa, C.S. Mermelstein, C.M. Chagas, S. Holtzer, and H. Holtzer. 1990. MyoD converts primary dermal fibroblasts, chondroblasts, smooth muscle, and retinal pigmented epithelial cells into striated mononucleated myoblasts and multinucleated myotubes. Proc. Nat1. Acad. Sci. 87: 79887992.

Chomczynski, P. and N. Sacchi. 1987. Single-step method of RNA isolation by acid guanidinium thiocyanate-phenolchloroform extraction. Anal. Biochem. 162: 156-159. 
Christian, J.L., J.A. McMahon, A.P. McMahon, and R.T. Moon. 1991. Xwnt-8, a Xenopus Wnt-1/int-1-related gene responsive to mesoderm-inducing growth factors, may play a role in ventral mesodermal patterning during embryogenesis. Development 111: 1045-1055.

Dagle, J.M., D.L. Weeks, and J.A. Walder. 1991. Pathways of degradation and mechanism of action of antisense oligonucleotides in Xenopus laevis embryos. Antisense Res. Dev. 1: $11-20$.

Davis, R.L., H. Weintraub, and A.B. Lassar. 1987. Expression of a single transfected cDNA converts fibroblasts to myoblasts. Cell 51: 987-1000.

Dent, J.A., A.G. Polson, and M.W. Klymkowsky. 1989. A wholemount immunocytochemical analysis of the expression of the intermediate filament protein vimentin in Xenopus. $D e$ velopment 105: 61-74.

Dreyer, C. 1987. Differential accuion of oocyte nuclear proteins by embryonic nuclei of Xenopus. Development 101: 829846.

Emerson, C.P. Jr. 1993. Skeletal myogenesis: genetics and embryology to the fore. (Review). Curr. Opin. Genet. Dev. 3: 265-274.

Evan, G.I., G.K. Lewis, G. Ramsay, and J.M. Bishop. 1985. Isolation of monoclonal antibodies specific for human c-myc proto-oncogene product. Mol. Cell. Biol. 5: 3610-3616.

Frank, D. and R. Harland. 1991. Transient expression of XMyoD in non-somitic mesoderm of Xenopus gastrulae. Development 113: 1387-1393.

Gallie, D.R. 1991. The cap and poly(A) tail function synergistically to regulate mRNA translational efficiency. Genes \& Dev. 5: 2108-2116.

Govind, S. and R. Stewart. 1991. Dorsoventral pattern formation in Drosophila: Signal transduction and nuclear targeting. Trends Genet. 7: 119-125.

Gurdon, J.B., S. Fairman, T.J. Mohun, and S. Brennan. 1985. Activation of muscle-specific actin genes in Xenopus development by an induction between animal and vegetal cells of a blastula. Cell 41: 913-922.

Harland, R.M. and L. Misher. 1988. Stability of RNA in developing Xenopus embryos and identification of a destabilizing sequence in TFIIIA messenger RNA. Development 102: 837-852.

Harvey, R.P. 1990. The Xenopus MyoD gene: An unlocalized maternal mRNA predates lineage-restricted expression in the early embryo. Development 108: 669-680.

Hasty, P., A. Bradley, J.H. Morris, D.J. Edmondson, E.N. Olson, and W.H. Klein. 1993. Muscle deficiency and neonatal death in mice with a targeted mutation in the myogenin gene. Nature 364: 501-506.

Hemmati-Brivanlou, A. and R.M. Harland. 1989. Expression of an engrailed-related protein is induced in the anterior neural ectoderm of early Xenopus embryos. Development 106: 611-617.

Higuchi, R. 1990. Recombinant PCR. In PCR protocols: A guide to methods and application (ed. M.A. Innis, D.H. Gelfand, and J.J. Sninskyl, pp. 177-183. Academic Press, San Diego, CA.

Hopwood, N.D. and J.B. Gurdon. 1990. Activation of muscle genes without myogenesis by ectopic expression of $\mathrm{MyoD}$ in frog embryo cells. Nature 347: 197-200.

Hopwood, N.D., A. Pluck, and J.B. Gurdon. 1989. MyoD expression in the forming somites is an early response to mesoderm induction in Xenopus embryos. EMBO $/$. 8: 34093417.

1991. Xenopus Myf-5 marks early muscle cells and can activate muscle genes ectopically in early embryos. Devel- opment 111: 551-560.

Hopwood, N.D., A. Pluck, J.B. Gurdon, and S.M. Dilworth. 1992. Expression of XMyoD protein in early Xenopus laevis embryos. Development 114: 31-38.

Jones, E.A. and H.R. Woodland. 1987. The development of animal cap cells in Xenopus: A measure of the start of animal cap competence to form mesoderm. Development 101: 557563.

Kato, K. and J.B. Gurdon. 1993. Single-cell transplantation determines the time when Xenopus muscle precursor cells acquire a capacity for autonomous differentiation. Proc. Natl. Acad. Sci. 90: 1310-1314.

Keller, R.E. 1975. Vital dye mapping of the gastrula and neurula of Xenopus laevis. I. Prospective areas and morphogenetic movements of the superficial layer. Dev. Biol. 42: 222-241.

1991. Early embryonic development of Xenopus laevis. Methods Cell Biol. 6: 61-113.

Kimmelman, D., J.L. Christian, and R.T. Moon. 1992. Synergistic principles in development: Overlapping patterning systems in Xenopus mesoderm induction. Development 116: $1-9$.

Kintner, C.R. and J.P. Brockes. 1984. Monoclonal antibodies identify blastemal cells derived from dedifferentiating muscle in newt regeneration. Nature 308: 67-69.

Kobel, H.R. and L. DuPasquier. 1986. Genetics of polyploid Xenopus. Trends Genet. 2: 310-315.

Krieg, P.A. and D.A. Melton. 1985. Developmental regulation of a gastrula-specific gene injected into fertilized Xenopus eggs. EMBO J. 4: 3463-3471.

Krieg, P.A., S.M. Varnum, W.M. Wormington, and D.A. Melton. 1989. The mRNA encoding elongation factor la (EF-la) is a major transcript at the midblastula transition in Xenopus. Dev. Biol. 133: 93-100.

Miner, J.H. and B. Wold. 1990. Herculin, a fourth member of the MyoD family of myogenic regulatory genes. Proc. Natl. Acad. Sci. 87: 1089-1093.

Miner, J.H., J.B. Miller, and B.J. Wold. 1992. Skeletal muscle phenotypes initiated by ectopic MyoD in transgenic mouse heart. Development 114: 853-860.

Munroe, D. and A. Jacobson. 1990. mRNA poly(A) tail, a 3 enhancer of translational initiation. Mol. Cell. Biol. 10: 3441-3455.

Murre, C., P. McCaw, and D. Baltimore. 1989. A new DNAbinding and dimerization motif in immunoglobulin enhancer binding, daughterless, MyoD, and myc proteins. Cell 56: 777-783.

Nabeshima, Y., K. Hanaoka, M. Hayasaka, E. Esumi, L. Shaowei, I. Nonaka, and Y. Nabeshima. 1993. Myogenin gene disruption results in perinatal lethality because of severe muscle defect. Nature 364: 532-535.

Newport, J. and M. Kirschner. 1982. A major developmental transition in early Xenopus embryos. II. Control of the onset of transcription. Cell 30: 687-696.

Nieuwkoop, P.D. 1969. The formation of mesoderm in urodelean amphibians. I. Induction by endoderm. Wilhelm Roux's Arch. Dev. Biol. 102: 341-373.

Nieuwkoop, P.D. and J. Faber. 1967. Normal table of Xenopus laevis (Daudin), 2nd ed. North Holland Publishing Company, Amsterdam, The Netherlands.

Olson, E.N. 1992. Interplay between proliferation and differentiation within the myogenic lineage. Dev. Biol. 154: 261272.

Rhodes, S.J. and S.F. Konieczny. 1989. Identification of MRF4: A new member of the muscle regulatory factor gene family. Genes \& Dev. 3: 2050-2061.

Roth, S., D. Stein, and C. Nüsslein-Volhard. 1989. A gradient of 
nuclear localization of the dorsal protein determines dorsoventral pattern in the Drosophila embryo. Cell 59: 11891202.

Roth, M.B., A.M. Zahler, and J.A. Stolk. 1991. A conserved family of nuclear phosphoproteins localized to sites of polymerase II transcription. J. Cell. Biol. 115: 587-596.

Rudnicki, M.A., T. Braun, S. Hinuma, and R. Jaenisch. 1992. Inactivation of $\mathrm{MyoD}$ in mice leads to upregulation of the myogenic HLH gene Myf- 5 and results in apparently normal muscle development. Cell 71: 383-390.

Rudnicki, M.A., P.N.J. Schnegelsberg, T. Braun, H.H. Arnold, and R. Jaenisch. 1993. MyoD or Myf-5 is required for the function of skeletal muscle. Cell 75: 1351-1359

Rupp, R.A.W. and H. Weintraub. 1991. Ubiquitous MyoD transcription at the midblastula transition precedes inductiondependent expression in the presumptive mesoderm. Cell 65: 927-937.

Rushlow, C.A., K. Han, J.L. Manley, and M. Levine. 1989. The graded distribution of the dorsal morphogen is initiated by selective nuclear transport in Drosophila. Cell 59: 11651177.

Scales, J.B., E.N. Olson, and M. Perry. 1990. Two distinct Xenopus genes with homology to $\mathrm{MyoDl}$ are expressed before somite formation in early embryogenesis. Mol. Cell. Biol. 10: $1516-1524$.

Sive, H.L. 1993. The frog prince-ss: A molecular formula for dorsoventral patterning in Xenopus. Genes \& Dev. 7: 1-12.

Slack, J.M.W. 1993. Embryonic induction. Mech. Dev. 41:91107.

Smith, W.C. and R.M. Harland. 1992. Expression cloning of noggin, a new dorsalizing factor localized to the Spemann organizer in Xenopus embryos. Cell 70: 829-840.

Sokol, S., J.L. Christian, R.T. Moon, and D.A. Melton. 1991. Injected Wnt RNA induces a complete body axis in Xenopus embryos. Cell 67: 741-752.

Suldarwati, S. and P.D. Nieuwkoop. 1971. Mesoderm formation in the anuran Xenopus laevis (Daudin). Wilhelm Roux's Arch. 166: 189-204.

Tapscott, S.J., R.L. Davis, M.J. Thayer, P.F. Cheng, H. Weintraub, and A.B. Lassar. 1988. MyoDl: A nuclear phosphoprotein requiring a Myc homology region to convert fibroblasts to myoblasts. Science 242: 405-411.

Thayer, M.J., S.J. Tapscott, R.L. Davis, W.R. Wright, A.B. Lassar, and $\mathrm{H}$. Weintraub. 1989. Positive autoregulation of the myogenic determination gene MyoD1. Cell 58: 241-248.

Thomsen, G., T. Woolf, M. Whitman, S. Sokol, J. Vaughan, W. Vale, and D.A. Melton. 1990. Activins are expressed early in Xenopus embryogenesis and can induce axial mesoderm and anterior structures. Cell 63: 485-493.

Turner, D.L. and H. Weintraub. 1994. Expression of achaetescute homolog 3 in Xenopus embryos converts ectodermal cells to a neural fate. Genes \& Dev. (in press).

Vandromme, M., G. Carnac, C. Gauthier-Rouviere, D. Fesquet, N. Lamb, and A. Fernadez. 1994. Nulcear import of the myogenic factor $\mathrm{MyoD}$ requires cAMP-dependent protein kinase activity but not the direct phosphorylation of MyoD. J. Cell Sci. 107: 613-620.

Weintraub, H. 1993. The MyoD family and myogenesis: Redundancy, networks, and thresholds. Cell 75: 1241-1244.

Weintraub, H., S.J. Tapscott, R.L. Davis, M.J. Thayer, M.A. Adam, A.B. Lassar, and A.D. Miller. 1989. Activation of muscle-specific genes in pigment, nerve, fat, liver, and fibroblast cell lines by forced expression of MyoD. Proc. Natl. Acad. Sci. 89: 5434-5438.

Weintraub, H., R. Davis, S. Tapscott, M. Thayer, M. Krause, R. Benezra, T.K. Blackwell, D. Turner, R. Rupp, S. Hollenberg,
Y. Zhuang, and A.L. Lassar. 1991a. The MyoD gene family: Nodal point during specification of the muscle cell lineage. Science 251: 761-766.

Weintraub, H., V.J. Dwarki, I. Verma, R. Davis, S. Hollenberg, L. Snider, A. Lassar, and S.J. Tapsoctt. 1991b. Muscle-specific transcriptional activation by MyoD. Genes \& Dev. 5: 13771386.

Whiteside, S.T. and S. Goodbourn. 1993. Signal transduction and nuclear targeting: Regulation of transcription factor activity by subcellular localisation. J. Cell Sci. 104: 949-955.

Whiteway, M., D. Dignard, and D.Y. Thomas. 1992. Dominant negative selection of heterologous genes: Isolation of Candida albicans genes that interfere with Saccharomyces cerevisiae mating-factor induced cell cycle arrest. Proc. Natl. Acad. Sci. 89: 9410-9414.

Woodland, H.R. 1993. Identifying the three signals. Curr. Biol. 3: 27-30.

Wright, W.E., D.A. Sassoon, and V.K. Lin. 1989. Myogenin, a factor regulating myogenesis, has a domain homologous to MyoDl. Cell 56: 607-617. 


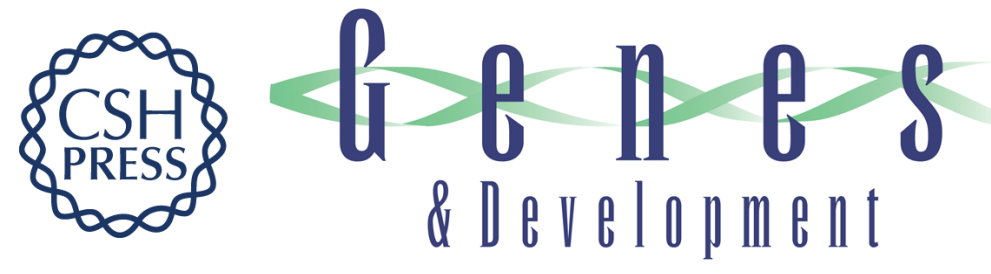

\section{Xenopus embryos regulate the nuclear localization of XMyoD.}

R A Rupp, L Snider and H Weintraub

Genes Dev. 1994, 8:

Access the most recent version at doi:10.1101/gad.8.11.1311

References This article cites 70 articles, 27 of which can be accessed free at:

http://genesdev.cshlp.org/content/8/11/1311.full.html\#ref-list-1

License

Email Alerting Receive free email alerts when new articles cite this article - sign up in the box at the top Service right corner of the article or click here.

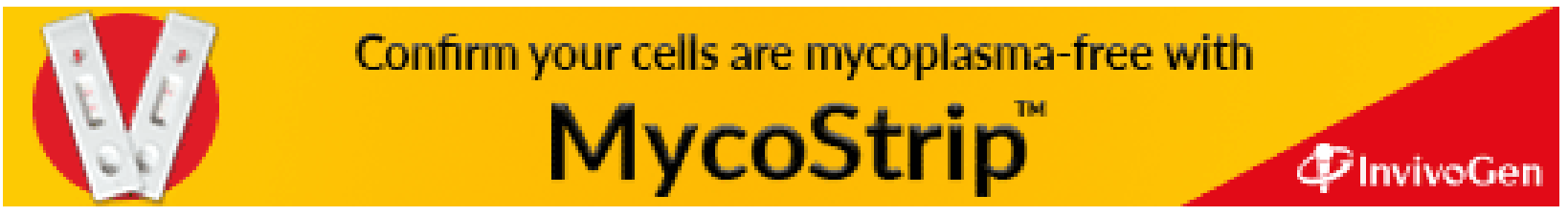

